\title{
Silk Protein as a Fetal Bovine Serum Substitute for Animal Cell Culture
}

\author{
You-Young Jo*, HaeYong Kweon, Sang Deok Ji, Jong Gil Kim, and Kee Young Kim \\ Sericultural and Apicultural Materials Division, National Institute of Agricultural Science, RDA, Wanju 55365, Republic of Korea
}

Received: January 30, 2019 / Revised: March 7, 2019 / Accepted: March 21, 2019

\begin{abstract}
Fetal Bovine Serum (FBS) is an essential substance added to animal cell culture medium. However, its composition is unclear causing problems such as development of an immune response when cultured cells are transplanted into the human body. In this study, silk sericin, silk fibroin, and hemolymph obtained from silkworms were added to the cell culture medium in order to determine if it can replace FBS. After establishment of the cell culture, cell proliferation and expression levels of cell growth-related genes were compared with those of control cells (cells cultured in the medium with 10\% FBS). Results showed that the test group treated with silk fibroin extracted from a Korean silkworm variety, Kumokjam could replace $10 \%$ FBS. In addition, expression levels of cell growth related genes such as Fibronectin and TGF- $\beta 1$ increased significantly in cells cultured using silk fibroin, depending on the concentration used in cell adhesion and cell proliferation [24]. To date, no studies have been conducted to find a replacement for FBS. Thus, this study was carried out to develop a substitute for FBS by using silkworm-derived alternatives such as silkworm hemolymph, silk sericin, and silk fibroin, which are cheap and have various physiological effects, cell promoting effects, and can be mass produced.
\end{abstract}

Keywords: FBS, silk sericin, silk fibroin, silkworm hemolymph

\section{Introduction}

With the development of tissue engineering and regenerative medicine, cell therapy will become the future of medical industry. Nowadays, many researches are being done about cell culture technology such as culture apparatus, culture medium and cell preservation technology. Currently, the products for cell therapy used in clinical treatment is prepared by washing FBS-containing components in the final product, however, proteins present in FBS are absorbed into cells and are not completely removed by simple washing $[1,2]$. Although FBS is rich in growth factors (GF) and low molecular weight molecules like hormones, it has drawbacks such

\section{*Corresponding author}

Tel: +82-63-238-2873, Fax: +82-63-238-3832

E-mail: yyjo@korea.kr

๑ 2019, The Korean Society for Microbiology and Biotechnology as undefined composition, lot-to lot variation, risk of bovine spongiform encephalitis (BSE), contamination risk from mycoplasma and immune reactions, and cost as high as $90 \%$ of total cost [2]. Therefore, studies on finding alternatives for FBS have become a major field of cell and tissue culture research [3]. Allogeneic humanderived replacements such as human umbilical cord blood serum (UCBS), serum, plasma, platelet rich plasma (PRP) and platelets were mainly studied [4-9]. However, human-derived supplements are very expensive and difficult to supply in large quantities.

Silkworm (Bombix mori), a representative insect producing silk that is capable of mass rearing, has been domesticated by humans for at least 5,000 years. It eats only mulberry leaves and becomes a fifth instar larva through four times molting. It builds a cocoon, turns into a pupa, turns into a moth, goes out a cocoon, and lays eggs after mating. 
Silkworm hemolymph, a silkworm fluid that is responsible for nutrition and immunity, has been confirmed having an effect of prolonging cell life by inhibiting apoptosis by substances such as staurosporine, camptothecin, and actinomycin [10-12]. Therefore, the possibility of replacing FBS with silkworm hemolymph in insect cell culture has been reported by studying the mechanism of inhibition of cell death in HeLa cell [13, 14].

Silkworm cocoon (silk) is composed of fibroin, a fibrous protein, and sericin an adhesive protein surrounding fibroin [15]. In the past, sericin was removed for improvement of gloss and touch in garment production. Recently, sericin has been applied and studied as a biomaterial with interest in the potential of sericin for wound closure due to its strong hydrophilicity, sterilizing power, and low inflammation response [16, 17]. It has also been reported that a low molecular weight sericin of 5 to $100 \mathrm{kDa}$ in the culture of animal cells grows the proliferative capacity of hybrid cell lines and T lymphocytes due to the role of mitogenic factor in serum-free medium [18]. Morikawa et al. successfully cultured pancreatic islets in serum-free medium containing sericin, since it facilitated the secretion of insulin [19]. In addition, it has been found out that serum-free freezing medium supplemented with sericin is available for the cryopreservation of bovine embryos and rat pancreatic islet [20, 21]. Fibroin is a linear polypeptide with little or no immune response. It is mechanically robust, biodegradable, and biocompatible that is why it is known to be useful for biomedical and biotechnology application as a biomaterial $[22,23]$. Moreover, it has been known to excel in cell adhesion and cell proliferation [24]. To date, no studies have been conducted on finding a replacement for FBS. Thus, this study was carried out to develop a substitute for FBS by using silkworm-derived material such as silkworm hemolymph, silk sericin, and silk fibroin which are cheap and have various physiological activities, cell promoting effects, and mass production capability.

\section{Materials and Methods}

\section{Experimental materials}

The experimental materials used in this study were obtained from five varieties of silkworm Bombyx mori (Kumokjam, Baegokjam, Daesungjam, Goldensilk, and
Yeonnokjam) which were bred in Korea and designated as encouraging varieties by the Korean government.

\section{Preparation of silkworm hemolymph and tyrosinase inac- tivation}

Silkworm hemolymph was collected from a leg of fifth instar larvae silkworms using a syringe. To inactivate tyrosinase in silkworm hemolymph ( $\mathrm{SH})$, the $\mathrm{SH}$ were heated with different time and temperature and protein changes using SDS-PAGE were observed. The SH for cell culture were heat-treated at $60^{\circ} \mathrm{C}$ for $30 \mathrm{~min}$ and were then chilled and centrifuged. The supernatant filtered with a $0.2 \mu \mathrm{m}$ membrane filter was used for supplement in the medium.

\section{Preparation of silk sericin and silk fibroin}

Sericin and fibroin were obtained from the cocoons of silkworm. First, sericin was prepared by adding $3000 \mathrm{ml}$ of distilled water to $100 \mathrm{~g}$ of silkworm cocoon and extracting it for $5 \mathrm{~h}$ at $120^{\circ} \mathrm{C}$, under $0.1 \mathrm{MPa}$ using a high temperature and high pressure machine which was then followed by lyophilization. The lyophilized sericin was dissolved by distilled water and was used for supplement in the medium. The degummed silk fibroin was dissolved in $\mathrm{C}_{2} \mathrm{H}_{5} \mathrm{OH}: \mathrm{H}_{2} \mathrm{O}: \mathrm{CaCl}_{2}(2: 8: 1)$ molar ratio at $85^{\circ} \mathrm{C}$ under continuous stirring for 7,8 , and $10 \mathrm{~h}$, respectively. The aqueous silk fibroin solution was obtained after dialysis of 3 days in distilled water and lyophilized. The lyophilized fibroin was dissolved by distilled water and used as supplement in the medium. All supplement, sericin, and fibroin were filtered with a $0.2 \mu \mathrm{m}$ membrane filter.

\section{Cell culture}

L929 cells (KCLB No.10001) were purchased from Korean Cell Line Bank. 500 cells/well were seeded on 96 well plates with RPM1640 (GenDEPOT, USA) medium supplemented with Antibiotic-Antimycotic (GenDEPOT), at $37^{\circ} \mathrm{C}$ in $5 \%$ carbon dioxide. Silkworm hemolymph $(5 \%$, $10 \%)$, silk sericin $(0.25 \%, 0.5 \%)$ and silk fibroin $(0.05 \%$, $0.1 \%, 0.15 \%$ ) were treated instead of FBS in the culture medium, and cultured for 1, 4, 7, and 10 days. As a control, medium containing 10\% FBS (GenDEPOT) was used. The cell proliferation was measured using Ez-cytox (DOGEN, Korea) according to the manual. 
Table 1. The primer pairs used to analyze gene expressions by PCR.

\begin{tabular}{cl}
\hline \multicolumn{1}{c}{ Gene } & \multicolumn{1}{c}{ Primer sequence $\left(5^{\prime}\right.$ to ${ }^{\prime}$ ) } \\
\hline $\begin{array}{c}\text { Collagenase } \\
\text { type I }\end{array}$ & Forward : ACGGCTGCACGAGTCACAC \\
Collagenase & Reverse : GGCAGGCGGGAGGTCTT \\
type III & Reverse : TTGCCTTGCGTGTTTGATATTC \\
Fibronectin & Forward : AGAGCAAGCCTGAGCCTGAAG \\
& Reverse : TCGCCAATCTTGTAGGACTGACC \\
TGF- $\beta 1$ & Forward : TGAACCAAGGAGACGGAATACAGG \\
& Reverse : GCCATGAGGAGCAGGAAGGG \\
GAPDH & Forward : ACGGCAAATTCAACGGCACAG \\
& Reverse : AGACTCCACGACATACTCAGCAC \\
\hline
\end{tabular}

\section{Gene expression}

The level of expression of the cell growth-related genes, Collagenase type I, Collagenase type III, Fibronectin, and TGF- $\beta 1$ were analyzed. Total RNA was prepared with TRIZOL reagent (Invitrogen, USA) according to the protocol of the manufacturer. AmfiRivert 1-step RT-PCR kit (GenDEPOT) was used for cDNA synthesis and PCR (Polymerase Chain Reaction).

PCR primers for gene expression analysis are shown in Table 1. The PCR reaction were predenaturated at $94^{\circ} \mathrm{C}$ for $4 \mathrm{~min}$ and then cycled 35 times at $94^{\circ} \mathrm{C} / 60 \mathrm{sec}$, $50^{\circ} \mathrm{C} / 60 \mathrm{sec}$, and $72^{\circ} \mathrm{C} / 60 \mathrm{sec}$, followed by a final $10 \mathrm{~min}$ extension at $72^{\circ} \mathrm{C}$ in a Takara thermal cycler dice touch (TP350, Takara, Australia). PCR products were separated by electrophoresis on a 1.0\% agarose gel and visualized by ultraviolet-induced fluorescence and then were analyzed using Gel capture program (E-Gel Imager, lifetechnologies, USA).

\section{Results and Discussion}

\section{Effect of silkworm hemolymph}

Silkworm hemolymph (SH) has tyrosinase activity that produces melanin via intermediary quinones. The production of toxic quinones in the medium consequently inhibits the cell growth [13]. Thus heat treatment was attempted to inactivate the tyrosinase in the $\mathrm{SH}$ before adding hemolymph to culture medium. To investigate the composition change of $\mathrm{SH}$ by heat treatment, molecular weight distribution of $\mathrm{SH}$ was examined (Fig. 1). It was found out that the $\mathrm{SH}$ main proteins (30 kDa and $70 \mathrm{kDa}$ ) were not changed by heat treatment time at $60^{\circ} \mathrm{C}$ and that $30 \mathrm{kDa}$ protein was destroyed by increasing temperature. All heat-treated $\mathrm{SH}$ remained clear and stable at room temperature for several hours. Since the $30 \mathrm{kDa}$ protein of $\mathrm{SH}$ was known to inhibit apoptosis and promote cell proliferation, we used $\mathrm{SH}$ that were heat-treated at $60^{\circ} \mathrm{C}$ for $30 \mathrm{~min}$ for media supplement and observed cell proliferation.

No satisfactory results were obtained to replace $10 \%$ FBS in SH of all varieties tested. In addition, no significant difference was found with increasing hemolymph. The addition of $\mathrm{SH}$ obtained from Daesungjam and Goldensilk showed a cell proliferative effect by increasing incubation time and exhibited a similar effect to that of 5\% FBS added group (Fig. 2). This is similar to or better than the results for using silkworm hemolymph as an FBS replacement in insect cell culture [13]. SH has been known to have an effect of inhibiting apoptosis induced by auto-inducing factors and maintaining cell growth. It has also been used as an additive in insect
A

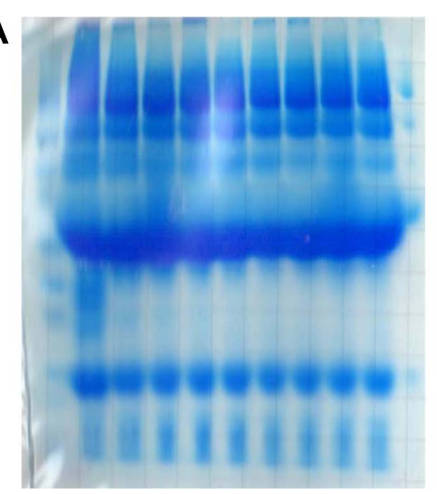

B

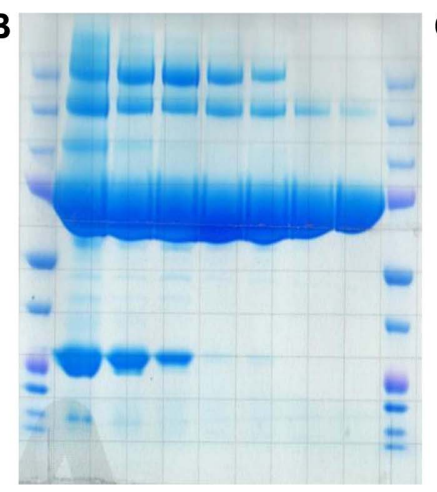

C

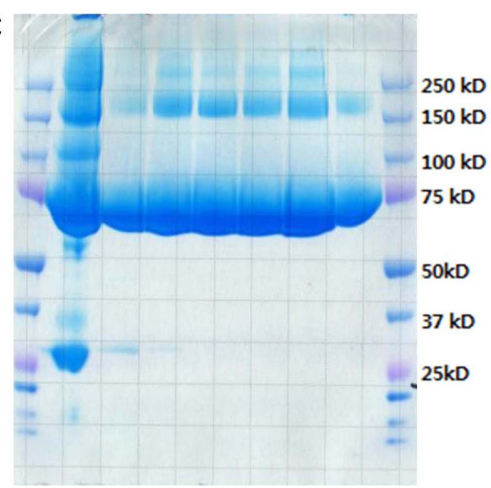

Fig. 1. Changes of silkworm hemolymph proteins by heat treatment. (A) Change with heat treatment time (each lane in order for $0,30,60,90,120,150,180,210,240 \mathrm{~min}$ ) at $60^{\circ} \mathrm{C}$; (B) Change due to heat treatment temperature for $30 \mathrm{~min}$ (in order at 60,66 , $69,72,75,78,81^{\circ} \mathrm{C}$ ); (C) Change due to heat treatment temperature for $60 \mathrm{~min}$ (in order at $60,66,69,72,75,78,81^{\circ} \mathrm{C}$ ). 

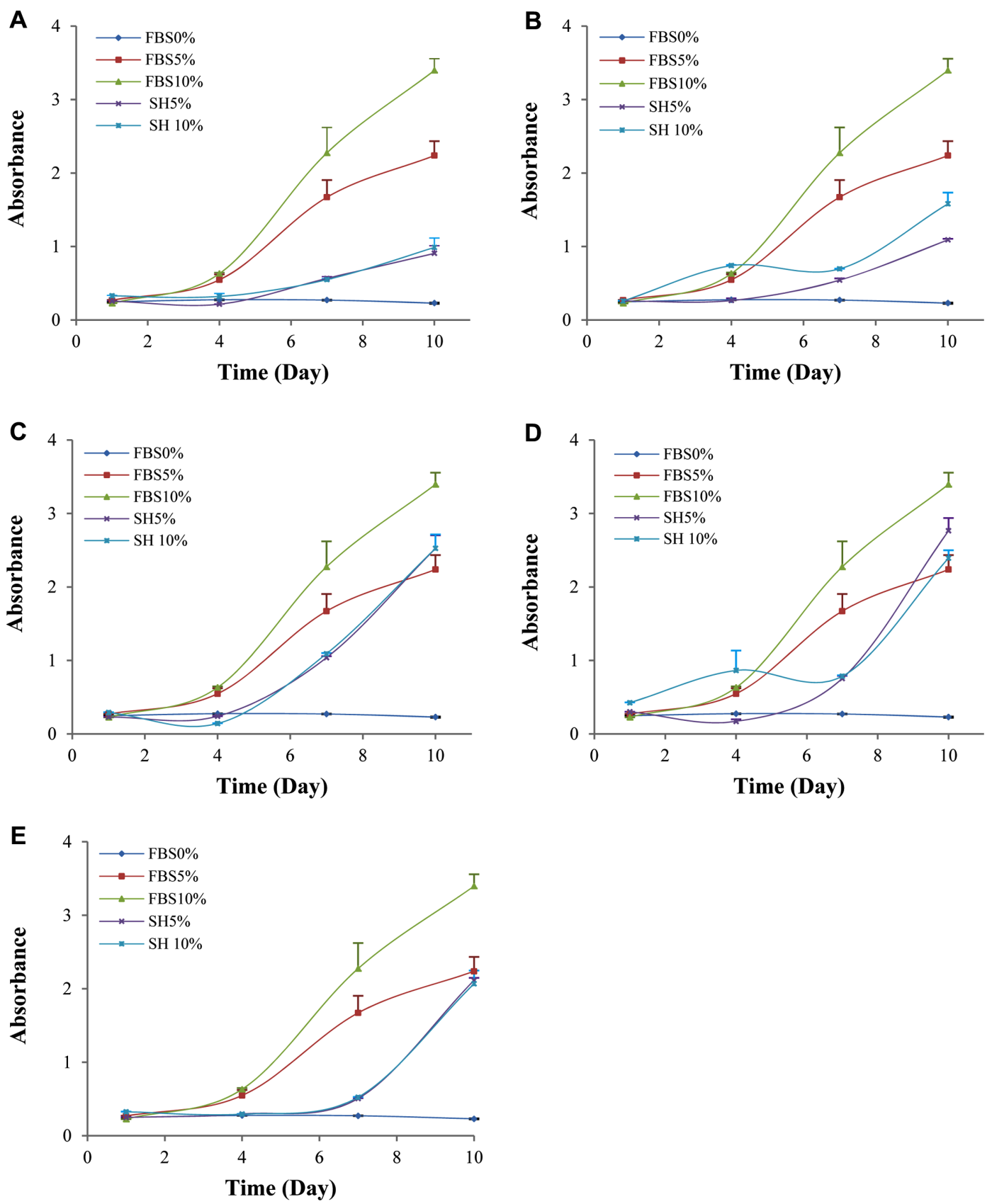

Fig. 2. Effect of silkworm hemolymph (SH) on silkworm varieties on the cell growth. Silkworm hemolymph (5\%, 10\%) were treated instead of FBS in the culture medium, and cultured for 1, 4, 7, and 10 days. (A) Kumokjam, (B) Baegokjam, (C) Daesungjam, (D) Goldensilk, (E) Yeonnokjam. The preferred symbols for graphs are $\bigcirc$,

•, ,

-,$\triangle$

$\boldsymbol{\Delta}, \nabla, \boldsymbol{\nabla}$.

and animal cell culture $[25,26]$. Cha et al. have observed cell proliferation and differentiation ability in serumfree medium supplemented with silkworm gland hydrolysate [27]. However, as described earlier, silkworm hemolymph was effective in proliferating cells but was unsatisfactory to replace $10 \% \mathrm{FBS}$. The reason for this is that the component of the silkworm hemolymph could not sufficiently replace the role of serum in the point of nutrients, growth factors and signal transduction substances necessary for cell culture. Also, there was a difference in effectiveness depending on the silkworm varieties. 


\section{Effect of silk sericin and fibroin}

Silk produced by Bombyx mori have a form that sericin surrounds two parallel fibroin fiber.

Sericin, an water-soluble glue-like protein, has useful properties such as antibacterial and antioxidant activity and UV resistance. It absorbs and releases moisture easily and it has tyrosinase and kinase inhibitory activity $[28,29]$. Sericin is well known to be highly safe, thus it can be added to drugs, over the counter drugs, cosmetics, foods, and health foods [30]. Fibroin is fibrous protein and has not only water absorbency, dyeing affinity, thermo tolerances, insulation properties and luster, but also excellent mechanical properties, good biocompatibility, biodegradability, and versatility of structural readjustments [29, 31]. Also, silk fibroin was recognized by the US Food and Drug Administration (FDA) as a biomaterial in 1993 [32]. Previous studies have shown that silk protein (sericin and fibroin) treatment is effective in cell proliferation and that there is a significant difference between silkworm varieties [33]. Sericin and fibroin from silkworm cocoons of five varieties were made to observe FBS substitution ability of silk proteins. The molecular weight of silk sericins used in the study ranged from 3.5 to $100 \mathrm{kDa}$ and there was no difference between the varieties. Baegokjam and Kumokjam fibroin had a molecular weight of less than $150 \mathrm{kDa}$ and $300 \mathrm{kDa}$, respectively. Both had no significant change in their molecular weight in relation to change in the dissolution time. Molecular weight distribution of Daesungjam Fibroin is similar to that of Kumokjam but decreased to less than $50 \mathrm{kDa}$ by dissolving $10 \mathrm{~h}$. In the case of Goldensilk and Yeonnokjam fibroin, the decrease in molecular weight was evident as the dissolution time increased (Fig. 3). All sericins used in this test were not cytotoxic and well dissolved in water and added to the serum-free medium for cell culture. In the case of $0.25 \%$ sericin added group, the effect of cell proliferaton was similar to that of $5 \%$ FBS.

However, when the sericin concentration was increased to $0.5 \%$, the cell proliferation was decreased regardless of silkworm varieties. The cell growth curves were similar to those of 5\% FBS supplemented medium at $0.25 \%$ sericin from Kumokjam, Baegokjam and, Daesungjam. In the case of $0.25 \%$ Goldensilk sericin, cell proliferation increased dramatically on the $10^{\text {th }}$ day of culture. However, none of the experimental groups treated with sericin found any efficacy to replace $10 \%$ FBS (Fig. 4). Tomohiro et al. have stated that the use of sericin is suitable not only for cryopreservation but also for the elimination of a potential source of biological contamination by serum or BSA [30]. Positive effects on cell proliferation was demonstrated thus there is great potential for practical applications in various cell types, such as pancreatic islet, hybridoma, bovine embryo, and fibroblast cell (L929) [20, 34-36]. However, neither the mechanism of growth stimulation nor the effective sericin fraction was known [37]. Although in this study, the effect of sericin in serum-free medium was similar to that of the 5\% FBS-supplemented group, it is considered to be an optimal material for producing products by recovering cells cultured as single-component proteins. The FBS replacement effect of fibroin surprisingly
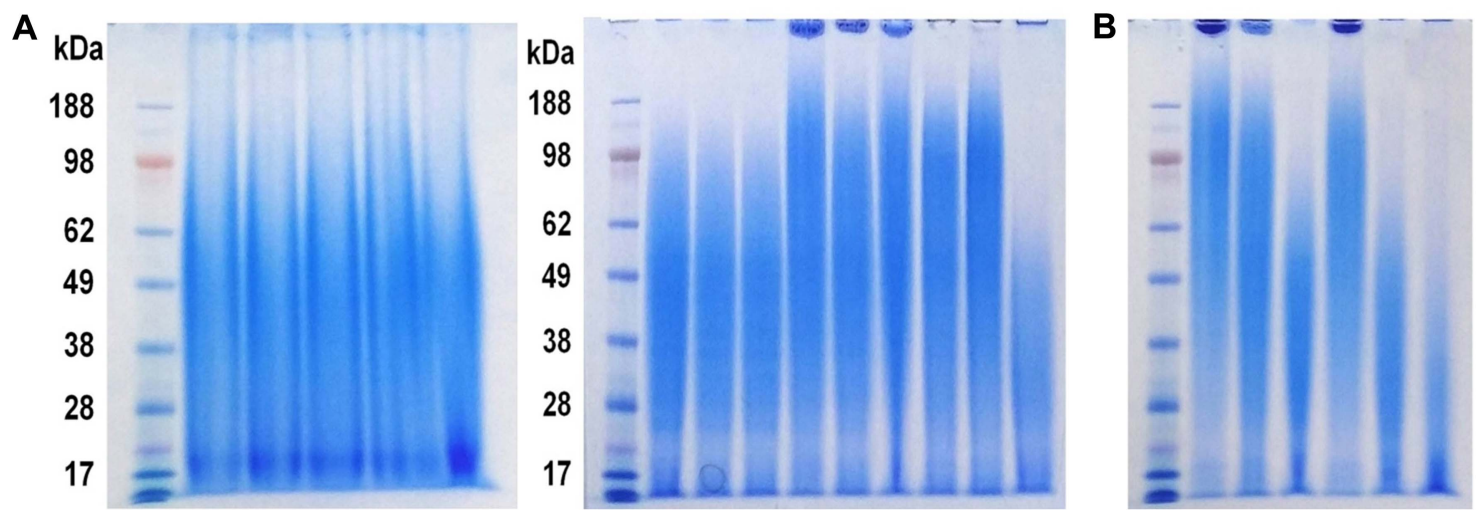

Fig. 3. Molecular weight silk proteins. (A) silk sericin; each lane in order Baegokjam, Kumokjam, Daesungjam, Goldensilk and Yeonnokjam (B) silk fibroin; each lane is grouped into three in order Baegokjam, Kumokjam, Daesungjam, Goldensilk and Yeonnokjam. Each group was dissolved for $7 \mathrm{~h}, 8 \mathrm{~h}$, and $10 \mathrm{~h}$ in order. 

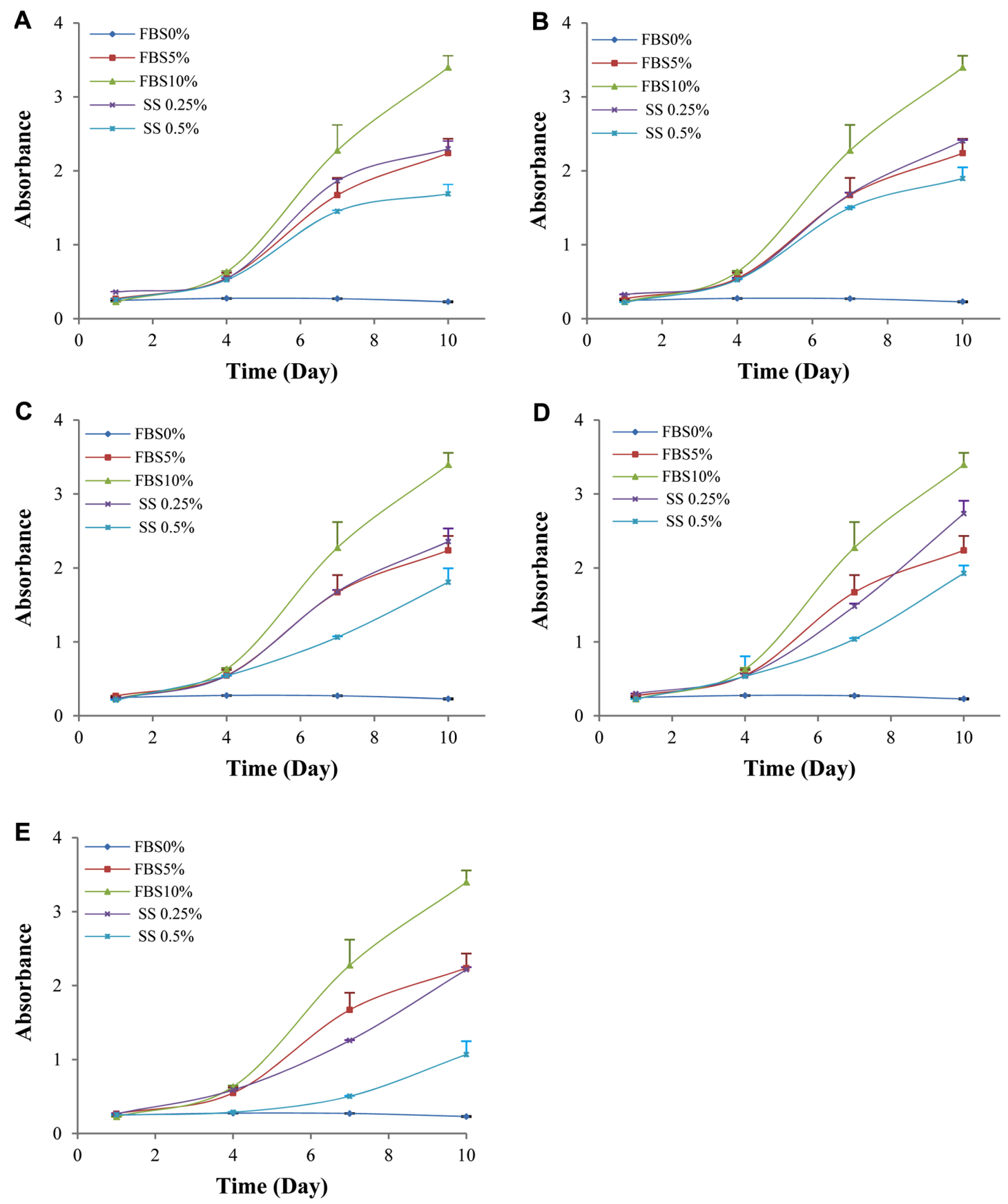

Fig. 4. Effect of silk sericin (SS) on silkworm varieties for FBS substitution. Silk sericin $(0.25 \%, 0.5 \%)$ were treated instead of FBS in the culture medium, and cultured for 1, 4, 7, and 10 days. (A) Kumokjam, (B) Baegokjam, (C) Daesungjam, (D) Goldensilk, (E) Yeonnokjam. The preferred symbols for graphs are $\bigcirc$,
,, ,
$\triangle, \triangle$,
$\boldsymbol{\Delta}, \nabla, \boldsymbol{\nabla}$.

showed similar or better cellular proliferative effects than the 10\% FBS supplemented group. Furthermore, the cell proliferating ability was different depending on the silkworm varieties, the fibroin dissolution time and the fibroin addition concentration. In the case of
Kumokjam fibroin (Fig. 5-I), when $0.05 \%$ and $0.1 \%$ of fibroin dissolved for $7 \mathrm{~h}$ were added, the level of cell proliferation was higher than the medium supplemented with $10 \%$ FBS. Fibroin dissolved for $8 \mathrm{~h}$ showed similar results to fibroin dissolved for $7 \mathrm{~h}$, but fibroin dissolved 
I)

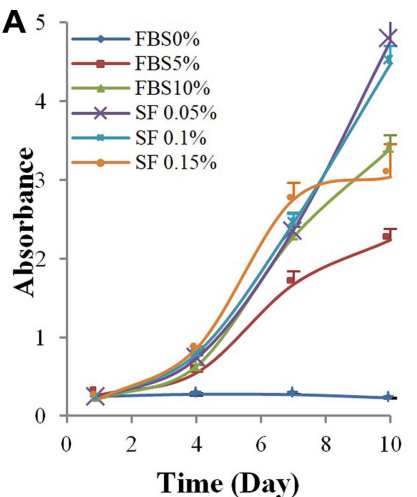

II)

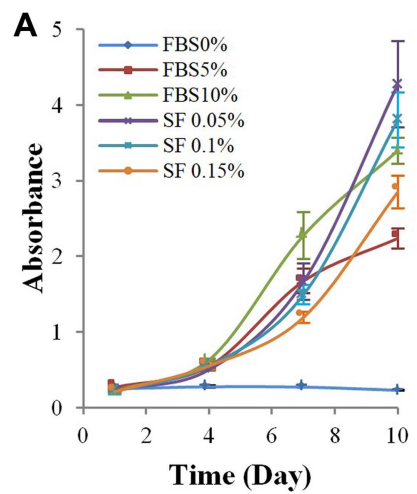

III)

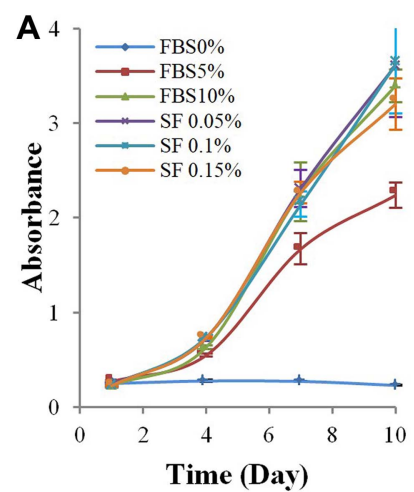

IV)

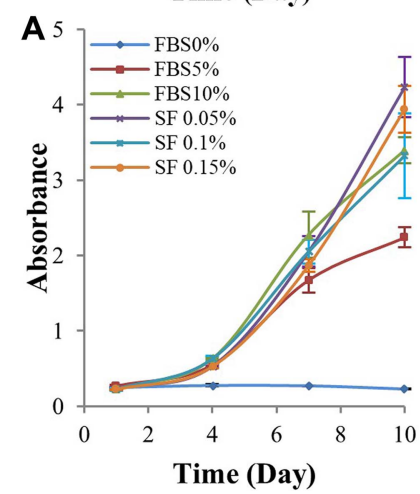

B

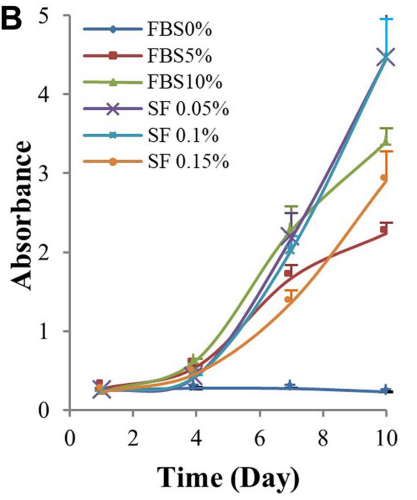

B

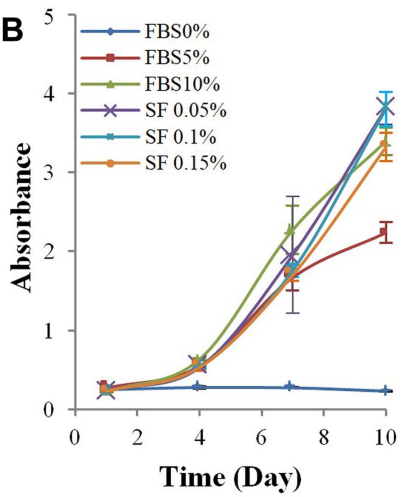

B

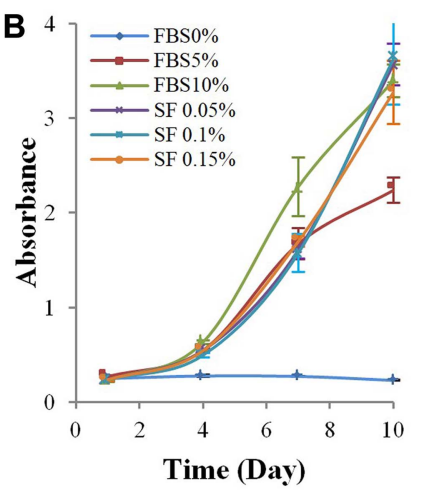

B

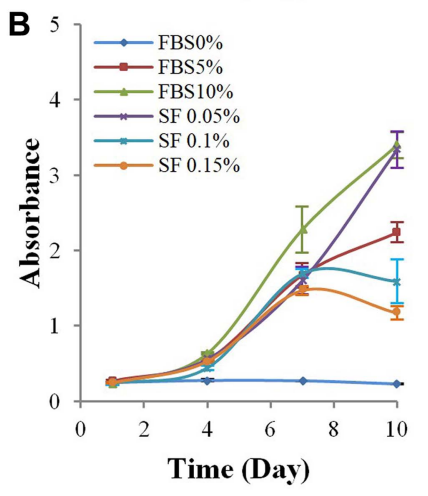

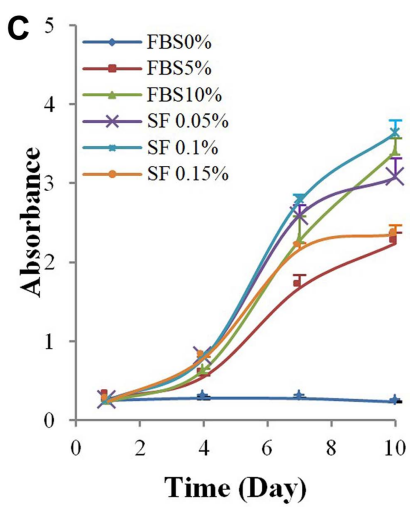

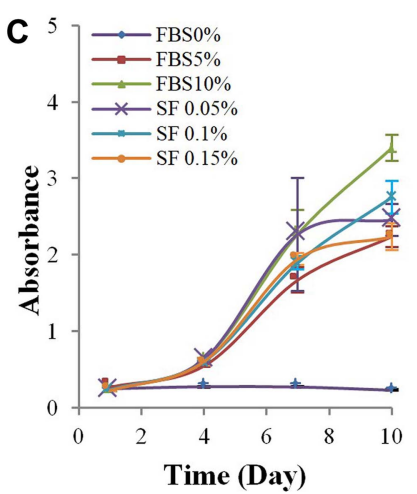

C
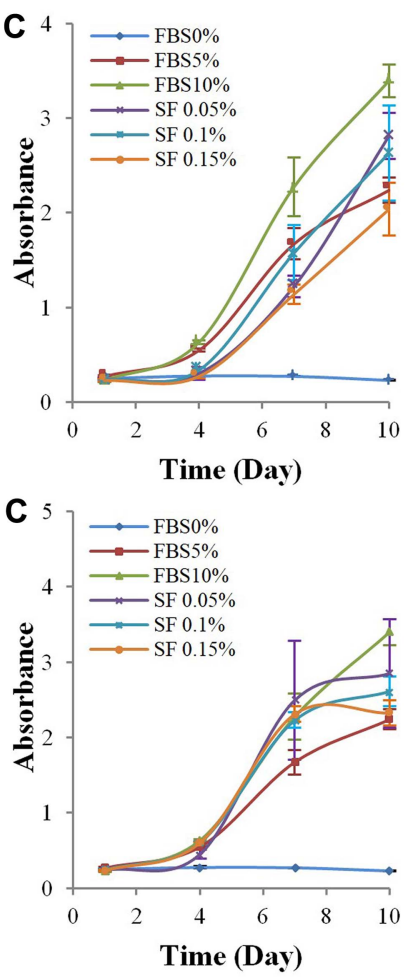

Fig. 5. Effect of silk fibroin (SF) on silkworm varieties for FBS substitution. Silk fibroin $(0.05 \%, 0.1 \%, 0.15 \%)$ were treated instead of FBS in the culture medium, and cultured for 1, 4, 7, and 10 days. SF was prepared by dissolving time for (A) $7 \mathrm{~h}$, (B) $8 \mathrm{~h}$, (C) $10 \mathrm{~h}$. (I) Kumokjam, (II) BaegOkJam, (III) Daesungjam, (IV) Goldensilk, (V) Yeonnokjam. The preferred symbols for graphs are $\bigcirc, \bullet, \square$, 


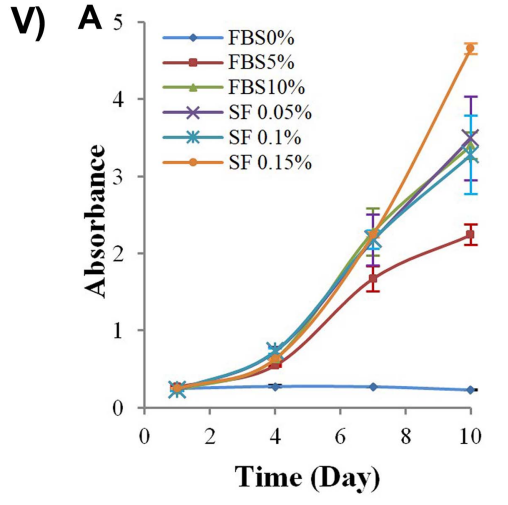

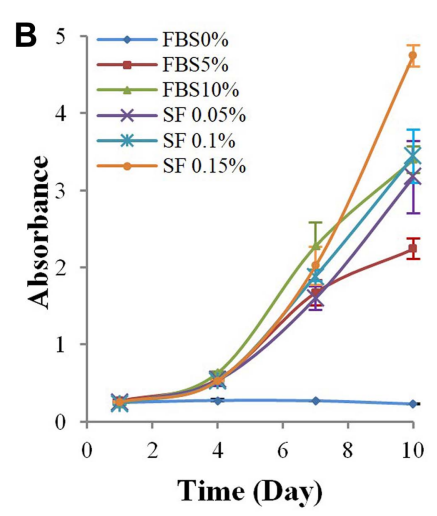

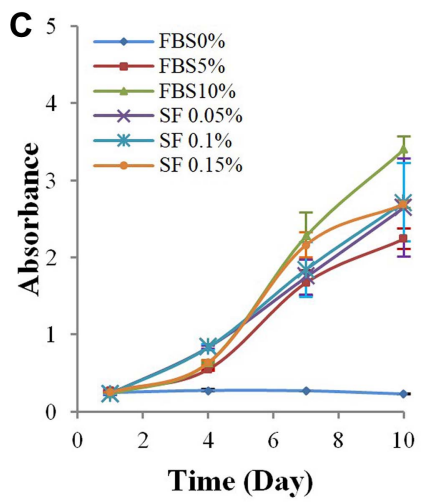

Fig. 5. Continued.

for $10 \mathrm{~h}$ was slightly less effective. The addition of $0.15 \%$ Kumokjam fibroin reduced the proliferation effect. In the case of Baegokjam fibroin (Fig. 5-II), the effect of dissolution time was very similar to that of Kumokjam fibroin but its proliferation effect was slightly decreased. Meanwhile, in Daesungjam fibroin (Fig. 5-III), the cell proliferative capacity was lower than that of Kumokjam and Baegokjam, but the growth was similar to that of 10\% FBS supplemented group. For Goldensilk fibroin (Fig. 5-IV), the fibroin dissolved for $7 \mathrm{~h}$ showed better cell proliferation ability than the $10 \%$ FBS treated group at all treated concentrations, but the effect of the fibroin treated group at the fibroin dissolved for $8 \mathrm{~h}$ and $10 \mathrm{~h}$ was lower than 10\% FBS treatment group. On Yeonnokjam fibroin (Fig. 5-V), fibroin dissolved for 7 and $8 \mathrm{~h}$ had a high cell proliferation effect depending on the treatment concentration but the fibroin dissolved for $10 \mathrm{~h}$ was less than the cell proliferation effect of 10\% FBS treated group. It has been reported that the treatment of silk fibroin induces NF-KB signaling activation [38]. Silk fibroin is considered as a promising biomaterial and has been studied in various forms of medical materials. However, no studies have yet been conducted on using silk fibroin as an alternative to FBS. As shown in this study, silk fibroin was sufficient to replace FBS and even more effective than FBS. The role of silk protein in the animal cell culture is more advantageous over FBS because it provides a high purity at low-cost when recovering cultured cells [18]. It has also been reported that silkworm cocoons contain flavonoids and derivatives thus exhibit antioxidant effects [39]. To investigate the effect of the flavonoid component of cocoon on the prolif- eration effects of the silk proteins, the total polyphenol and total flavonoid content of each tested fibroin and sericin, as well as their antioxidant activity, was determined (data not shown). The Kumokjam, Baegokjam, and Daesungjam make white cocoon while Goldensilk and Yeonnokjam makes yellow cocoon and light green cocoon, respectively. Total polyphenol contents of fibroins were about twice as high as that of sericins. Kumokjam, BaegOkJam, Daesungjam, and Goldensilk showed the highest value in $7 \mathrm{~h}$ dissolved fibroin and Yeonnokjam fibroin was the highest in $8 \mathrm{~h}$ dissolved fibroin. In the case of sericin, the total polyphenol content of Yeonnokjam was the highest, and it was about $20 \%$ higher than that of Kumokjam. The total flavonoid content of fibroin was $10 \%$ higher than that of sericin, but there was little difference in dissolution time. In the case of Yeonnokjam sericin, it contained the highest amount of flavonoids among all sericin and fibroin samples. This is thought to be caused by the effect of the light green cyan color of Yeonnokjam cocoon. Antioxidant activity was also higher in the fibroin test group than sericin, but there was no significant difference between the dissolution time and the varieties. Sericin and fibroin may have a positive effect on cell proliferation, although FBS replacement and antioxidant activity were not directly related.

\section{Cell growth-related gene expression levels by fibroin treatment}

The expression levels of cell growth-related gene such as Collagenase type I, Collagenase type III, Fibronectin, and TGF- $\beta 1$ were observed after cell culture with the 
FBS
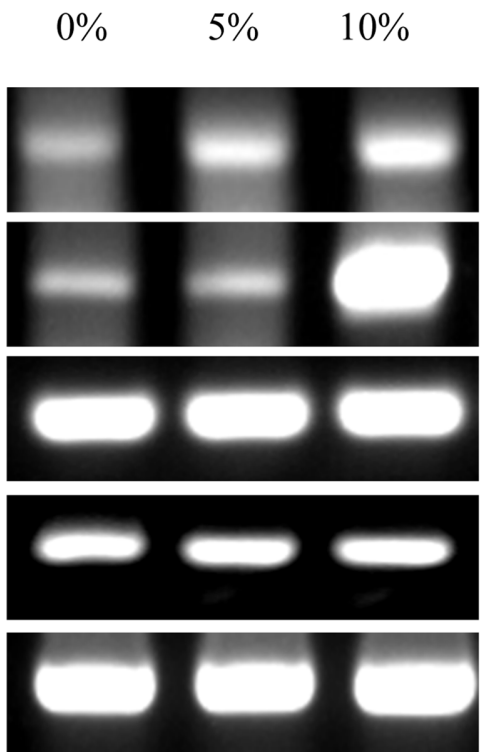

Silk fibroin
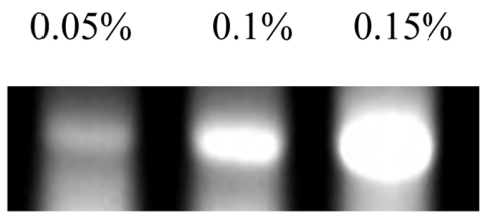

Fibronectin

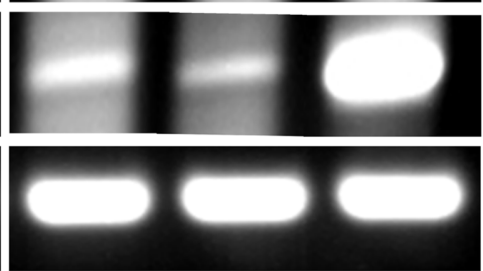

TGF- $\beta 1$

Collagenase III

Collagenase I

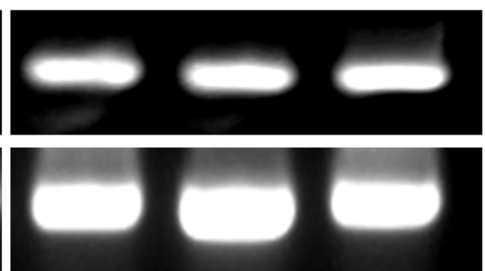

GAPDH

Fig. 6. Effect of silk fibroin from Kumokjam dissolved for $7 \mathrm{~h}$ on the expression level of genes associated with cell growth (for 7 days).

addition of 7-hour-dissolved Kumokjam fibroin which had the best FBS replacement effect to the serum-free medium (Fig. 6). Collagenase types I and III showed no change in the expression level depending on the concentration of FBS or silk. Collagenase promotes the cellular responses to injury and wound healing in vivo [40]. It is thought that Collagenase types I and III are always expressed in normal cell growth without being affected by the environment.

Fibronectin is involved in various cell interactions with extracellular matrix [41]. It is widely distributed in soluble forms such as plasma, cerebrospinal fluid, amniotic fluid, joint fluid, saliva, and inflammatory exudate. It plays an important role in cell differentiation, growth, cell attachment, and migration. Fibronectin expression was increased sharply with increasing concentration of silk fibroin compared with the increase in the amount of fibronectin expression with increasing FBS concentration. It is believed that silk fibroin acted as an extracellular matrix leading to cell growth. Transforming growth factor- $\beta 1$ (TGF- $\beta 1$ ) gene expression levels also showed similar results with silk fibroin treatment and $10 \%$ FBS treatment. TGF- $\beta 1$, a cytokine that has various functions in cell differentiation, is an important immune regulatory factor that induces and inhibits immune and inflammatory responses [42]. TGF$\beta 1$ is involved in the synthesis and secretion of extracellular matrix proteins and is known to play an important role in tissue regeneration, including osteogenesis and wound healing [43]. In this study, it was confirmed that silk fibroin is more effective than 10\% FBS although the gene expression level and growth curve were not exactly the same. In order to investigate more detailed mechanism how silk fibroin could replace FBS, microarray analysis would be needed to identify all of the genes involved in cell growth.

\section{Acknowledgments}

This study was carried out with the support of the 'Research Program for Agricultural Science \& Technology Development' (PJ01262602), National Institute of Agricultural Science, Rural Development Administration, Republic of Korea.

\section{Conflict of Interest}

The authors have no financial conflicts of interest to declare. 


\section{References}

1. Spees JL, Gregory CA, Singh H, Tucker HA, Peister A, Lynch PJ, et al. 2004. Internalized antigens must be removed to prepare hypoimmunogenic mesenchymal stem cells for cell and gene therapy. Mol. Ther. 9: 747-756.

2. Van der Valk J, Bieback K, Buta C, Cochrane B, Dirks WG, Fu J, et al. 2018. Fetal Bovine Serum (FBS): past-present-future. ALTEX 35: 99-118.

3. Van der Valk J, Brunner D, De Smet K, Fex SA, Honegger P, Knudsen $L E$, et al. 2010. Optimization of chemically defined cell culture media - Replacing fetal bovine serum in mammalian in vitro methods. Toxicol. In Vitro 24: 1053-1063.

4. Hassan G, Kasem I, Soukkarieh C, Aljamali M. 2017. A simple method to isolate and expand human umbilical cord derived mesenchymal stem cells: Using explant method and umbilical cord blood serum. Int. J. Stem Cells 10: 184-192.

5. Blazquez-Prunera A, Diez JM, Gajardo R, Grancha S. 2017. Human mesenchymal stem cells maintain their phenotype, multipotentiality, and genetic stability when cultured using a defined xenofree human plasma fraction. Stem Cell Res. Ther. 8: 103-113.

6. Lykov AP, Bondarenko NA, Surovtseva MA, Kim II, Poveshchenko OV, Pokushalov EA, et al. 2017. Comparative effects of plateletrich plasma, platelet lysate, and fetal calf serum on mesenchymal stem cells. Bull. Exp. Biol. Med. 163: 757-760.

7. Kocaoemer A, Kern S, Klüter H, Bieback K. 2007. Human AB serum and thrombin-activated platelet-rich plasma are suitable alternatives to fetal calf serum for the expansion of mesenchymal stem cells from adipose tissue. Stem Cells 25: 1270-1278.

8. Castells-Sala C, Martorell J, Balcells MC. 2017. A human plasma derived supplement preserves function of human vascular cells in absence of fetal bovine serum. Cell Biosci. 7: 41-48.

9. Kandoi S, Praveen KL, Patra B, Vidyasekar P, Sivanesan D, Vijayalakshmi S, et al. 2018. Evaluation of platelet lysate as a substitute for FBS in explant and enzymatic isolation methods of human umbilical cord MSCs. Sci. Rep. 9: 12439-12450.

10. Mun JY, Lee HS, Lee KG, Kweon HY, Jo YY, Yeo JH. 2013. Effects of matured silkworm hemolymph on suppressing melanin synthesis. J. Seric. Entomol. Sci. 51: 207-210.

11. Choi SS, Rhee WJ, Park TH. 2002. Inhibition of human cell apoptosis by silkworm hemolymph. Biotechnol. Prog. 18: 874-878.

12. Kim EJ, Park HJ, Park TH. 2003. Inhibition of apoptosis by recombinant 30K protein originating from silkworm hemolymph. Biochem. Biophys. Res. Commun. 308: 523-528.

13. Ha SH, Park TH, Kim SE. 1996. Silkworm hemolymph as a substitute for fetal bovine serum in insect cell culture. Biotechnol. Tech. 10: 401-406.

14. Rhee WJ, Park JH, Hahn JS, Park TH. 2013. Anti-apoptotic mechanism of silkworm hemolymph in HeLa cell apoptosis. Process Biochem. 48: 1375-1380.

15. Putthanarat S, Eby RK, Adams WW, Liu GF. 1996. Aspects of the morphology of the silk of Bombyx mori. J. Macromol. Sci. Part A. 33: 899-911.
16. Nayak S, Talukdar S, Kundu SC. 2012. Potential of 2D crosslinked sericin membranes with improved biostability for skin tissue engineering. Cell Tissue Res. 347: 783-794.

17. Aramwit P, Sangcakul A. 2007. The effects of sericin cream on wound healing in rats. Biosci. Biotechnol. Biochem. 71: 2473-2477.

18. Terada S, Sasaki M, Yanagihara K, Yamada H. 2005. Preparation of silk protein sericin as mitogenic factor for better mammalian cell culture. J. Biosci. Bioeng. 100: 667-671.

19. Morikawa M, Kimura T, Murakami M, Katayama K, Terada S, Yamaguchi A. 2009. Rat islet culture in serum-free medium containing silk protein sericin. J. Hepatobiliary Pancreat. Surg. 16: 223228.

20. Isobe $T$, Ikebata $Y$, Onitsuka T, Wittayarat M, Sato $Y$, Taniguchi M, et al. 2012. Effect of sericin on preimplantation development of bovine embryos cultured individually. Theriogenology 78: 747752.

21. Ohnishi K, Murakami M, Morikawa M, Yamaguchi A. 2012. Effect of the silk protein sericin on cryopreserved rat islets. J. Hepatobiliary Pancreat. Sci. 19: 354-360.

22. Panossian A, Ashiku S, Kirchhoff $\mathrm{CH}$, Randolph MA, Yaremchuk MJ. 2001. Effects of cell concentration and growth period on articular and ear chondrocyte transplants for tissue engineering. Plast. Reconstr. Surg. 108: 392-402.

23. Stoddart MJ, Grad S, Eglin D, Alini M. 2009. Cells and biomaterials in cartilage tissue engineering. Regen. Med. 4: 81-98.

24. Sumida M, Sutthikhum V. 2015. Fibroin and sericin-derived bioactive peptides and hydrolysates as alternative sources of food additive for promotion of human health: A review. Res. Knowl. 1: 1-17.

25. Pakkianathan BC, Singh NK, König S, Krishnan M. 2015. Antiapoptotic activity of $30 \mathrm{kDa}$ lipoproteins family from fat body tissue of silkworm, Bombyx mori. Insect Sci. 22: 629-638.

26. Choi SS, Rhee WJ, Park TH. 2005. Beneficial effect of silkworm hemolymph on a CHO cell system: Inhibition of apoptosis and increase of EPO production. Biotechnol. Bioeng. 91: 793-800.

27. Cha HM, Kim SM, Choi YS, Park JS, Lim JH, Hwang SG, et al. 2015. Serum-free media supplement from silkworm gland for the expansion of mesenchymal stem cells. Tissue Eng. Regen. Med. 12: 53-59.

28. Kundu SC, Dash BC, Dash R, Kaplan DL. 2008. Natural protective glue protein, sericin bioengineered by silkworms: potential for biomedical and biotechnological applications. Prog. Polym. Sci. 33: 998-1012.

29. Mondal M, Trivedy K, Kumar SN. 2007. The silk proteins, sericin and fibroin in silkworm, Bombyx mori Linn., - A review. Caspian J. Env. Sci. 5: 63-76.

30. Isobe $T$, Ikebata $Y$, Onitsuka T, Do LT, Sato $Y$, Taniguchi $M$, et al. 2013. Cryopreservation for bovine embryos in serum-free freezing medium containing silk protein sericin. Cryobiology 67: 184187.

31. Qi Y, Wang H, Wei K, Yang Y, Zheng RY, Kim IS, et al. 2017. A review of structure construction of silk fibroin biomaterials from single structures to multi-level structures. Int. J. Mol. Sci. 18: 237-257. 
32. Melke J, Midha S, Ghosh S, Ito K, Hofmann S. 2016. Silk fibroin as biomaterial for bone tissue engineering. Acta. Biomater. 31: 1-16.

33. Chung DE, Kim SK, Jo YY, Kweon HY, Lee KG, Kim HB. 2015. Cell proliferation of silk proteins obtained from Bombyx mori silkworm varieties. J. Seric. Entomol. Sci. 53: 92-96.

34. Ohnishi K, Murakami M, Morikawa M, Yamaguchi A. 2012. Effect of the silk protein sericin on cryopreserved rat islets. J. Hepatobiliary Pancreat. Sci. 19: 354-360.

35. Terada S, Nishimura T, Sasaki M, Yamada H, Miki M. 2002. Sericin, a protein derived from silkworms, accelerates the proliferation of several mammalian cell lines including a hybridoma. Cytotechnology 40: 3-12.

36. Cao TT, Zhang YQ. 2015. Viability and proliferation of L929, tumour and hybridoma cells in the culture media containing sericin protein as a supplement or serum substitute. Appl. Microbiol. Biotechnol. 99: 7219-7228.

37. Sehnal F. 2008. Prospects of the practical use of silk sericins. Entomol. Res. 38: S1-S8.
38. Park YR, Sultan MT, Park HJ, Lee JM, Ju HW, Lee OJ, et al. 2018. NF$\kappa \mathrm{B}$ signaling is key in the wound healing processes of silk fibroin. Acta. Biomater. 67: 183-195.

39. Pornanong A. 2012. Flavonoids and carotenoids in silkworm cocoons, pp. 87-97. In Pornanong A (ed.), Silk: Properties, Production and Uses, Nova Science Publishers.

40. Riley KN, Herman IM. 2005. Collagenase promotes the cellular responses to injury and wound healing in vivo. J. Burns Wounds 4: e8.

41. Pankov R, Yamada KM. 2002. Fibronectin at a glance. J. Cell Sci. 115: 3861-3863.

42. McCartney-Francis N, Mizel D, Wong H, Wahl L, Wahl S. 1990. TGF- $\beta$ regulates production of growth factor and TGF- $\beta$ by human peripheral blood monocytes. Growth Factors 4: 27-35.

43. Yamada Y. 2000. Association of a Leu ${ }^{10} \longrightarrow$ Pro polymorphism of the transforming growth factor- $\beta 1$ with genetic susceptibility to osteoporosis and spinal osteoarthritis. Mech. Ageing Dev. 1160: 113-123. 